Citation: Sözbilir, F., Factors Affecting Individuals' Creativity Performance: Paternalist Leadership, Management Innovation and Psychological Ownership, BMIJ, (2020), 8(4): 929-954, doi: http://dx.doi.org/10.15295/bmij.v8i4.1606

\title{
FACTORS AFFECTING INDIVIDUALS' CREATIVITY PERFORMANCE: PATERNALIST LEADERSHIP, MANAGEMENT INNOVATION AND PSYCHOLOGICAL OWNERSHIP
}

Fikret SÖZBILİR ${ }^{1}$

\author{
Received Date (Başvuru Tarihi): \\ $26 / 08 / 2020$ \\ Accepted Date (Kabul Tarihi): \\ $8 / 10 / 2020$ \\ Published Date (Yayın Tarihi): \\ $10 / 12 / 2020$
}

\begin{abstract}
Keywords:

Paternalistic Leadership,

Management Innovation,

Psychological Ownership,

Creativity Performance
\end{abstract}

JEL Codes:

M11, M12, M21
Paternalistic leadership, management innovation, psychological ownership and creativity performance are the most important approaches for organisations to gain a competitive advantage. This study aims to examine the impact of paternalistic leadership, management innovation, and psychological ownership on creativity performance. Besides, it aimed to provide recommendations based on results regarding the impact of paternalistic leadership and management innovation on psychological ownership and creativity performance. In this empirical study, the data on perceptions concerning paternalistic leadership, management innovation, psychological ownership, and creativity performance were gathered using a questionnaire completed by 119 school vice-principals and 94 school principals, all employed in schools in Artvin, Turkey. The data were analysed with the SmartPLS software and presented in seven tables. The findings showed that management innovation and psychological ownership have a positive impact on creativity performance. The results also revealed that paternalistic leadership has a significant impact on management innovation and psychological ownership. However, it is determined that paternalistic leadership does not have a significant impact on creativity performance.

\section{BIREYLERIN YARATICI PERFORMANSINI ETKILEYEN FAKTÖRLER: BABACAN LIDERLIK, YÖNETIM İNOVASYONU VE PSIKOLOJIKK SAHIIPLENME}

$\ddot{O Z Z}$

\begin{abstract}
Anahtar Kelimeler:
Babacan Liderlik,

Yönetim Inovasyonu,

Psikolojik Sahiplenme,

Yaratıcı Performans
\end{abstract}

JEL Kodlarn:

M11, M12, M21
Babacan liderlik, yönetim inovasyonu, psikolojik sahiplenme ve yaratıcı performans örgütlerin rekabetçi avantaj kazanmaları için en önemli yaklaşımlardır. Bu çalışamnın amacı, babacan liderlik, yönetim inovasyonu ve psikolojik sahiplenmenin yaratıcı performans üzerindeki etkisini incelemektir. Ayrica, babacan liderlik ve yönetim inovasyonunun, psikolojik sahiplenme ve yaratıcı performans üzerindeki etkisine ilişkin sonuçlara dayalı olarak önerilerde bulunmak da amaçlanmıştır. Bu ampirik çalışmada, babacan liderlik, yönetim inovasyonu, psikolojik sahiplenme ve yaratıcı performans algısına dair veriler Türkiye'de Artvin ilinde çalışan 119 okul müdür yardımcısı ve 94 müdüründen anket yoluyla toplanmıştır. Toplanan veriler SmartPLS yazılımı ile analiz edilmiş ve tablolar halinde sunulmuştur. Bulgular, yönetim inovasyonu ve psikolojik sahiplenmenin yaratıcı performans üzerinde olumlu etkisi olduğunu göstermiştir. Aynı zamanda babacan liderliğin yönetim inovasyonu ve psikolojik sahiplenme üzerinde olumlu etkisi olduğunu olduğunu ortaya çıkarmıştır. Ancak, babacan liderliğin yaratıcı performans üzerinde anlamlı bir etkisi olmadığını göstermiştir.

\footnotetext{
${ }^{1}$ Assoc. Prof. Dr., Artvin Coruh University, Hopa F.E.A.S., Business Administrative Dept., $\underline{\text { fsozbilir08@hotmail.com, }}$ https://orcid.org/0000-0003-2665-1795
}

Business \& Management Studies: An International Journal Vol::8 Issue:4 Year:2020, 929-954

Bu makale, araştırma ve yayın etiğine uygun hazırlanmış ve 


\section{INTRODUCTION}

Leadership styles are an essential factor in developing the attitudes and behaviours of employees toward organisations. In order to be a leader, it is necessary to have the ability to guide and influence all of his followers in the best way. Leaders empower their workers to achieve their goals, put employees' needs ahead of their own needs, and help them develop (Anwar, 2013). Paternalistic leaders behave like a father taking care of their employees in their off-the-job lives and help to improve the welfare of employees. In return, subordinates show their voluntary loyalty, obedience, and compliance with their paternalistic leader (Pasa, Kabasakal, \& Bodur, 2001; Pellegrini \& Scandura, 2006). Paternalistic leadership is defined as "a style that combines strong discipline and authority with fatherly benevolence and moral integrity" (Farh \& Cheng, 2000, p. 94). Although seen as a benevolent dictatorship in the Western context, the paternalist attitude of a leader is seen as positive especially in collectivistic business cultures, such as in Turkey, India, Pakistan (Pellegrini \& Scandura, 2006), Malaysia (Ansari, Ahmad, \& Aafaqi, 2004), China, Taiwan (Farh, Cheng, Chou, \& Chu, 2006) and Japan (Uhl-Bien, Tierney, Graen, \& Wakabayashi, 1990) with high power distance (Pellegrini \& Scandura, 2006; Aycan, Kanungo, Mendonca, Yu, Deller, Stahl, \& Kurshid, 2000). According to Pellegrini and Scandura (2006), there is a relationship between paternalistic leadership and communication, decision-making, and motivation of employees. Paternalistic leadership is more accepted in patriarchal societies and businesses where the power distance is high (Yeşiltaş, 2013). Also, many studies have been conducted to examine the effect of paternalistic leadership on organisational cynicism (Sungur, Özer, Sayg1lı, \& Uğurluoğlu, 2019; Nal, 2019), job satisfaction (Nal \& Tarım, 2017), work engagement (Nal \& Sevim, 2020), job motivation (Nal \& Sevim, 2019), employee voiceover (Özyılmaz \& Ataç, 2019), and job performance and intention to leave the job (Uğurluoğlu, Aldoğan, Turgut, \& Özatkan, 2018), in Turkey.

Management innovation is another strategic approach to management, which means engaging in new management practices, processes, and structures for better organisational success by significantly changing the currently performed managerial work (Mol \& Birkinshaw, 2009; Volberda, Bosch, \& Mihalache, 2014). Many studies 
have revealed that there is a positive relationship between management innovation and company performance due to increased productivity (Mol \& Birkinshaw, 2009; Damanpour, Walker, \& Avellaneda, 2009; Camisón \& Villar-López, 2014; Volberda et al., 2014). Previous studies also revealed that management innovation gives a competitive advantage to companies and assists innovative and creative workers in their careers (Mol \& Birkinshaw, 2006). At the same time, knowledge improves the capacity of management innovation (Mol \& Birkinshaw, 2009). Therefore, leaders should proactively use different and new managerial practices.

Psychological ownership is described as a "mental state where one develops a strong sense of possessiveness towards an object in the absence of any legal entitlement over it" (Shukla \& Singh, 2015, p. 231). Psychological ownership stems from the sensitivity based on equality and influence emotion and knowledge sharing for effectiveness. This ownership sense includes ownership of organisational problems and responsibility being taken by all stakeholders regardless of their hierarchical status (Shukla \& Singh, 2015). Psychological contracts and focusing on the goal improve psychological ownership (Pierce, Kostova, \& Dirks, 2001), and in turn, psychological ownership increases altruism (good soldiers) (Griep, Wingate, \& Brys, 2017). Besides, psychological ownership leads to a feeling of capability, self-efficacy, and self-identity, which leads to creativity (Tierney \& Farmer, 2002; Tierney \& Farmer, 2011).

Creativity performance is defined as the number of new ideas generated and novel behaviours doing by the workers in performing their occupational activities (Wang \& Netemeyer, 2004). Generating and evaluating new solutions for old problems, looking at an old problem from a different perspective, identifying and solving new problems, and developing new ways to undertake daily activities represent creativity performance. The creativity of workers is an essential factor in increasing the efficiency and effectiveness of the organisation and prove a competitive advantage (Wang \& Netemeyer, 2004). According to Ding, Tang, Tang, and Posner (2014), festive mood improves creativity performance. Kurt (2013) found in her study that there is a positive relationship between paternalistic leadership and creative work. 
By giving information about each variable above, the importance of these variables for employees and organisations was explained. If the possible effects of such critical approaches on creative performance, which is vital for organisations, are determined, appropriate management policies can be followed by managers to increase creative performance in organisational activities. Although the relationships of these variables with creative performance have been investigated separately, their effect has not been investigated before. This paper aims to investigate directly impact of paternalist leadership, management innovation, and psychological ownership on creativity performance.

Previous research has examined the relationship between paternalistic leadership and creativity (Kurt, 2013; Wang, Tang, Naumann, \& Wang 2017; Lu, Li, Leung, Savani, \& Morris 2018; Wu, 2018). However, it was not encountered a study in the literature on whether paternalistic leadership, management innovation, and psychological capital combined have an impact on creative performance. The current study investigates whether there is an impact of paternalistic leadership, management innovation, and psychological ownership on creativity performance. Also, this study investigates the impact of paternalistic leadership on management innovation and psychological ownership. Furthermore, the current study points to the importance of paternalist leadership, management innovation, and psychological ownership in this interaction chain. These variables are considered meaningful by organisations since employees who are motivated and well managed tend to make an effort to increase their creativity performance (Lin, Ma, Zhang, Lin, \& Jiang, 2016; Wang, Chou, Wu, \& Cheng, 2018). Creativity performance has an impact on other factors of organisational commitment (Yüzbaşioglu \& Doğan, 2018), job satisfaction (Pellegrini, Scandura, \& Jayaraman, 2010), and loyalty (Pellegrini \& Scandura, 2006). This paper will contribute to advance the idea of creativity performance and determine which factors amplify it and how. 


\section{THEORETICAL BACKGROUND AND HYPOTHESIS DEVELOPMENT}

\subsection{Paternalistic Leadership and Management Innovation}

Birkinshaw, Hamel, and Mol (2008) defined management innovation as "the generation and implementation of a management practise, process, structure, or technique that is new to state of the art and is intended to further organisational goals" (p. 829). Fu, Li, and Si (2013) studied on 159 supreme leaders of high-tech enterprises in Chongqing, China, and the results showed that benevolence, a dimension of paternalistic leadership, had a positive effect on explorative innovation and exploitative innovation when the two types of innovation were taken into account. Tian and Sanchez (2017) explored how paternalistic leadership stimulated employees and examined the leader's innovative behaviours. Based on previous studies, the following hypothesis was developed to test whether paternalistic leadership has an impact on management innovation.

$\boldsymbol{H}_{1}$ : Paternalistic leadership has a significant and positive impact on management innovation.

\subsection{Paternalistic Leadership and Psychological Ownership}

Pierce et al. (2001) defined psychological ownership as "a state in which individuals feel as though the target of ownership (material or immaterial in nature) or a piece of it is "theirs" (i.e., "It is MINE!") (p. 299). It may also be referred to as the feeling of belonging to the workplace in which the individuals work and feeling like an owner of the workplace (Gino, 2015). Paternalistic leadership increases the feelings of work engagements (Nal \& Sevim, 2020), which also increases psychological ownership (Kirk, McSherry, \& Swain, 2015). According to Seppala (2016), the best leaders take a step back in the face of employees and continue to treat them humanely, act kindly to them, inspire to their employees in the workplace and make sure they take care of themselves to improve their psychological ownership. Previous studies determined that transformational leadership (Avey, Avolio, \& Crossley, 2009) and transactional leadership were positively related to psychological ownership (Bernhard \& O'Driscoll, 2011). Avey, Wernsing, and Palanski (2012), in their study on 845 working adults across multiple organisations in the USA, explored that ethical 
leadership has a positive and significant impact on psychological ownership. Besides, examined whether benevolent leadership had an impact on psychological ownership by surveying 166 professional managers working in 166 family businesses in China. The results of another research showed that benevolent leadership had a positive and indirect impact on the manager's psychological ownership (Zhu, Chen, Li, \& Zhou, 2013). Ethical leadership and benevolent leadership are known as two dimensions of paternalistic leadership. Current study examined the paternalistic leadership by combining ethical and benevolent leadership into one factor. Accordingly, the following hypothesis was proposed:

$\mathbf{H}_{2}$ : Paternalistic leadership has a significant and positive impact on psychological ownership.

\subsection{Paternalistic Leadership and Creativity Performance}

According to Dinh, Lord, Gardner, Meuser, Liden, and $\mathrm{Hu}$ et al. (2014), leadership theories have grown about creativity since the new millennium. Previous studies demonstrated that paternalistic leadership has an impact on creativity performance. Dedahanov, Lee, Rhee, and Yoon (2016) conducted a survey on 387 highly skilled employees in the Republic of Korea, and Kurt (2013) studied on 176 white-collar employees in Istanbul (Turkey), both revealing that the paternalistic (benevolent and moral) leadership style had an impact on creativity via employee's contribution through their ideas, suggestions, or opinions about work-related issues. In their study, Wang et al. (2017) researched in China, and the results showed that there is a relationship between paternalistic leadership and employee creativity. Also, Wang and Cheng (2010) and Wang et al. (2018) found that there was a positive and robust relationship via job autonomy as a moderator between paternalist leadership and creativity performance.

Similarly, Wu (2018) determined that paternalistic leadership had an impact on creative behaviour. To summarise, paternalistic leadership is related to creativity in different ways, such as employee creativity, creative behaviour, and indirect impact. Therefore, the following hypothesis was developed to test the impact of paternalistic leadership on creativity performance.

$\boldsymbol{H}_{3}$ : Paternalistic leadership has a significant and positive impact on creativity performance. 


\subsection{Management Innovation and Psychological Ownership}

Lee, Jeon, Kim, and Jung (2014), in their study with 248 employees working at SME's in area of DaeGu and Kyungbuk in the Republic of Korea, explored that psychological ownership affected innovative behaviour. Mustafa, Martin, \& Hughes (2016) argued that there is a positive relationship between psychological ownership and the discovery, exploitation of innovative ideas, and opportunities across the firm. Employees are more critical than soulless machines. If they are willing, they can be heroes who solve problems, innovate and create value by using their talents for the organisation. For this, love, rather than fear, must dominate the organisation. At the same time, an organisation should give its employees the necessary knowledge, skills, tools and permission to solve the problem (Hamel \& Breen, 2007). Due to primary human motives, innovative management approaches may improve ownership feelings of employees (Pierce et al., 2001), and based on this, and the following hypothesis was developed;

$H_{4}:$ Management innovation has a significant and positive impact on psychological ownership.

\subsection{Management Innovation and Creativity Performance}

Birkinshaw et al. (2008) defined management innovation as "a difference in the form, quality, or state overtime of the management activities in an organisation, where the change is a novel or unprecedented departure from the past" (p. 826). The results of previous researches (Mol \& Birkinshaw, 2009; Volberda et al., 2013; Kraśnicka, Głód, \& Wronka-Pośpiech, 2016) conclude that there is a positive relationship between management innovation and firm performance in terms of productivity growth. In addition to the definition mentioned above, Birkinshaw et al. (2008) argued that management innovation is inventing and implementing new management methods and techniques to achieve organisational goals. Wang and Netemeyer (2004) conceptualised creativity performance in terms of employees as the number of new ideas generated and novel behaviours exhibited by employees in performing their job activities. Novelty and intellectual productivity are the main factors of both management innovation and creativity performance. Based on these arguments, the following hypothesis was constructed: 


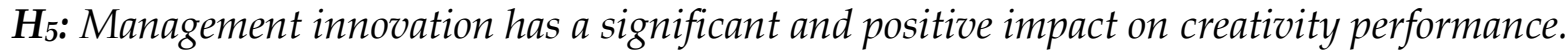

\subsection{Psychological Ownership and Creativity Performance}

Psychological ownership theory also comprises a human motive that gives rise to psychological ownership of a given goal, such as efficiency (Zhu et al., 2013). According to Parks, Ma, and Gallagher (2010), there is a relationship between psychological ownership and creativity. Previous studies have shown that psychological feelings and psychological ownership are related to creativity. Zhou and George (2001) conducted a study in which their results demonstrated that the job dissatisfaction of employees could be redirected into creativity if they perceived that there was support from the organisation and they wanted to stay in the organisation. Pickford, Joy, and Roll (2016) argued that psychological ownership of employees could be improved by supporting their work creatively. Under these conditions, it is worth making an effort and determining the factors that will increase the creativity performance of employees. Thus, for the current study, the following hypothesis was proposed:

$\boldsymbol{H}_{6}$ : Psychological ownership has a significant and positive impact on creativity performance.

Figure 1 depicts the proposed hypotheses, based on a theoretical background in the research.

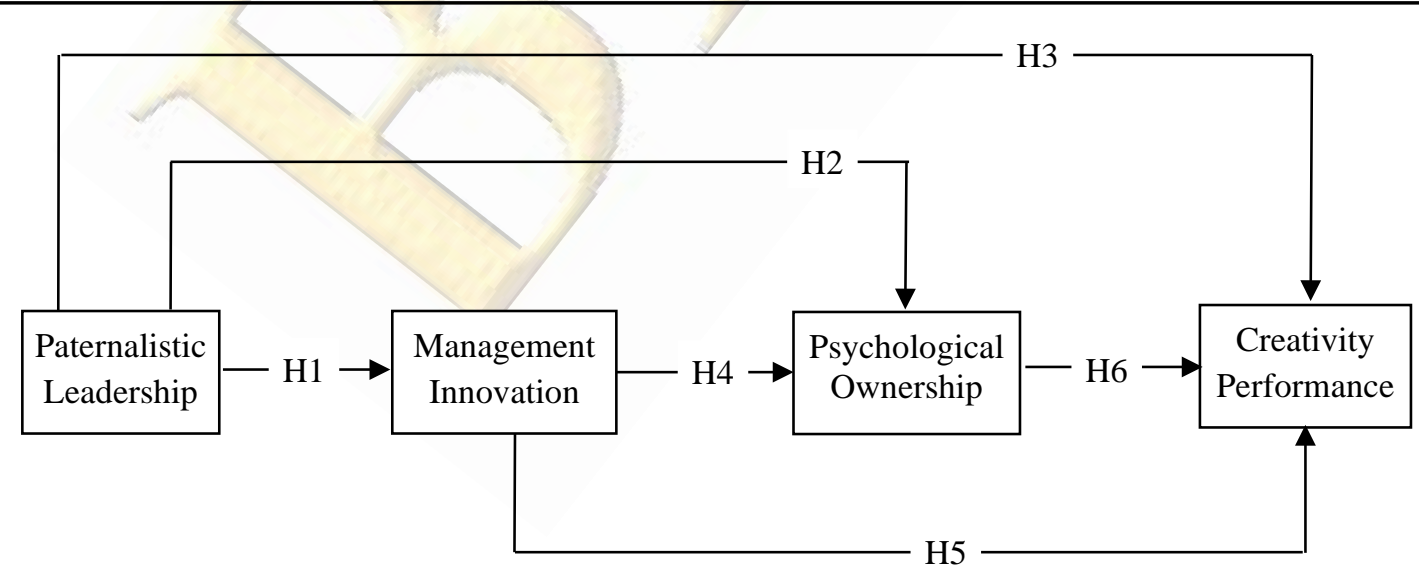

Figure 1. Research Model Summarizing Hypothesized Relationships 


\section{METHODOLOGY}

\subsection{Sample}

The universe and sample of the research were 250 teachers who were invited and attended a leadership seminar given by the author. Questionnaires were distributed to all participants in 2019. 213 questionnaires were returned from vice school principals $(\mathrm{n}=119)$, and school principals $(\mathrm{n}=94)$ (e.g., primary, secondary, and high schools) and the response rate was $85,2 \%$. In the Turkish national education system, school principals work under the district directors of the national department of education in the district and the provincial national education directors in the provinces. The vice school principals evaluated the school principals who, in turn, evaluated national education directors.

\subsection{Measures}

The questionnaire consisted of five parts. Data was gathered from vice school principals and school principals about their demographic information and perceptions on paternalistic leadership, management innovation, psychological ownership, and creative performance. The reason for choosing school administrators as a sample is that they are both manager and subordinate and to examine the reflections of leadership perceptions. For all scales, the respondents were asked to rate them using a five-point Likert scale of 1 to 5, ranging from strongly disagree to strongly agree. Paternalistic leadership was measured on a 13-item scale in responses to survey questions designed by Aycan (2006) and also used by Pellegrini and Scandura (2006). Scale items were translated from English to Turkish by the author and checked by an English lecturer. Management innovation was measured using a six-item scale developed by Vaccaro, Jansen, Van Den Bosch, \& Volberda (2012). The 12 psychological ownership items used in this study were developed by Shukla and Singh (2015). Creativity performance was measured using a six-item scale adapted from Wang and Netemeyer (2004).

\section{RESULTS}

Analyses were performed using the partial least squares (PLS) structural equation model (SEM) with SmartPLS 2.0.M3 software (Ringle et al., 2005). PLS-SEM 
path models consist of a measurement model and a structural model. When the data were analysed in terms of demographic characteristics, it was found that the majority of the respondents were male $(80.8 \%)$. Most of the school principals and viceprincipals were aged 36 to 55 years old $(67.1 \%)$. The respondents mostly had a graduate degree $(87.3 \%)$, with only $12.7 \%$ having a postgraduate degree. The monthly salary of $67.1 \%$ of the participants varied between 3,501 and 5,000 TRY $(1 \$=3.78$ TRY at time of writing). The tenure for participants ranged from 11 to 16 years $(56.3 \%)$. Sixty-two per cent of the respondents stated that they worked in their positions because they had an interest in this field. Further demographic characteristics of the respondents are given in Table 1.

Table 1. Demographic Characteristics of Respondents

\begin{tabular}{|c|c|c|c|c|c|}
\hline Variables & & & Variables & & \\
\hline Gender & $n$ & $\%$ & Education & $n$ & $\%$ \\
\hline Male & 172 & 80.8 & Graduate & 186 & 87.3 \\
\hline Female & 41 & 19.2 & Post graduate & 27 & 12.7 \\
\hline Total & 213 & 100.0 & Total & 213 & 100.0 \\
\hline Age & $n$ & $\%$ & Monthly salary/ income (TL) & $n$ & $\%$ \\
\hline $27-35$ & 61 & 28.6 & $2,900-3,500$ & 44 & 20.7 \\
\hline $36-45$ & 81 & 38.0 & $3,501-5,000$ & 143 & 67.1 \\
\hline $46-55$ & 62 & 29.1 & $5,001-6,500$ & 22 & 10.3 \\
\hline 56 and above & & 4.2 & 6,501 and more & 4 & 1.9 \\
\hline Total & 213 & 100.0 & Total & 213 & 100.0 \\
\hline Tenure in Organisation & $n$ & $\%$ & Total-experience & $n$ & $\%$ \\
\hline $7-10$ years & 33 & 15.5 & $7-10$ years & 39 & 18.3 \\
\hline $11-16$ years & 120 & 56.3 & $11-16$ years & 53 & 24.9 \\
\hline $17-22$ years & 21 & 9.9 & $17-22$ years & 48 & 22.5 \\
\hline 23-30 years & 29 & 13.6 & $23-30$ years & 59 & 27.7 \\
\hline 31 and above & & 4.7 & 31 years and above & 14 & 6.6 \\
\hline Total & 213 & 100.0 & Total & 213 & 100.0 \\
\hline
\end{tabular}

\begin{tabular}{lrr}
\hline Administrative position & $\boldsymbol{n}$ & $\mathbf{\%}$ \\
\hline School principal & 119 & 55.9 \\
Vice school principal & 94 & 44.1 \\
Total & 213 & 100.0 \\
\hline
\end{tabular}

Source: Created by the authors

\subsection{Evaluation of Measurement Model}

The measurement model comprised composite reliability to evaluate internal consistency and individual item reliability, and at the same time contained an average variance extracted (AVE) to evaluate convergent validity using the Fornell-Larcker 
criterion (Fornell \& Larcker, 1981) and enabled cross-loadings to detect discriminant validity. The primary criterion of internal consistency is Cronbach's alpha or composite reliability. Composite reliability values in the range of 0.70 to 0.95 can be regarded as satisfactory (Nunally \& Bernstein, 1994).

Both convergent validity and discriminant validity are used for the assessment of the validity of the measurement model. Convergent validity can be established by measuring AVE (Fornell \& Larcker, 1981). For AVE, the outer loading of all items should be 0.708 or above and statistically significant. Besides, their squared values $\left(0.708^{2}\right)$ must be equal to or higher than 0.50 . Therefore, the latent variable should explain at least $50 \%$ of the variance of each item (Hair, Hult, Ringle, \& Sarstedt, 2014). The results of the internal consistency and convergent validity are presented in Table 2.

Table 2. Results of The Internal Consistency

\begin{tabular}{rccccc}
\hline Variables & AVE & $\begin{array}{c}\text { Composite } \\
\text { Reliability }\end{array}$ & $\begin{array}{c}\text { Cronbach's } \\
\text { Alpha }\end{array}$ & Communality & Redundancy \\
\hline PL & 0.608 & 0.933 & 0.919 & 0.608 & \\
MI & 0.611 & 0.886 & 0.840 & 0.611 & 0.132 \\
PO & 0.647 & 0.948 & 0.939 & 0.647 & 0.073 \\
CP & 0.714 & 0.946 & 0.933 & 0.714 & 0.106 \\
\hline
\end{tabular}

PL: Paternalistic Leadership, MI: Management Innovation, PO: Psychological Ownership, CP: Creativity Performance Source: Created by the authors

Table 2 shows that the Cronbach's alpha values were above the recommended 0.707 criteria, and the composite reliability values of this study were calculated in the range of $0.88-0.94$, which indicates that the items performed well in capturing latent variables. Furthermore, the AVE values showed that every latent variable variance was explained in the range of $58-82 \%$ (Chin, 1989).

Discriminant validity is "the extent to which a construct is different from other constructs by empirical standards" (Hair et al., 2014), assessed by examining the indicator's cross-loading and Fornell-Larcker criterion. According to the FornellLarcker criterion, the square root of each latent variable's AVE values should be over the highest correlation with any other latent variable. 
Table 3. Results of The Crossloading Test Checking the Discriminant Validity of Construct

\begin{tabular}{ccccc}
\hline Variables & PL & MI & PO & CP \\
\hline PL.1 & $\mathbf{0 . 7 8 1 2}$ & 0.3731 & 0.3906 & 0.2664 \\
PL.2 & $\mathbf{0 . 8 3 1 5}$ & 0.4525 & 0.5051 & 0.2953 \\
PL.3 & $\mathbf{0 . 7 8 3 5}$ & 0.3650 & 0.4800 & 0.2283 \\
PL.4 & $\mathbf{0 . 7 4 2 8}$ & 0.2593 & 0.3650 & 0.2432 \\
PL.5 & $\mathbf{0 . 7 5 8 4}$ & 0.3493 & 0.3700 & 0.3143 \\
PL.8 & $\mathbf{0 . 7 4 4 9}$ & 0.3743 & 0.4396 & 0.3185 \\
PL.9 & $\mathbf{0 . 7 0 3 6}$ & 0.2700 & 0.4044 & 0.1473 \\
PL.10 & $\mathbf{0 . 8 4 3 9}$ & 0.3393 & 0.5107 & 0.1978 \\
PL.12 & $\mathbf{0 . 8 1 6 2}$ & 0.4338 & 0.4999 & 0.2929 \\
MI.1 & 0.3752 & $\mathbf{0 . 8 1 2 4}$ & 0.3539 & 0.3879 \\
MI.2 & 0.4068 & $\mathbf{0 . 8 5 5 7}$ & 0.3733 & 0.3261 \\
MI.3 & 0.3861 & $\mathbf{0 . 8 2 1 0}$ & 0.3231 & 0.3468 \\
MI.5 & 0.3712 & $\mathbf{0 . 7 6 4 1}$ & 0.3506 & 0.2929 \\
MI.6 & 0.2585 & $\mathbf{0 . 6 3 5 8}$ & 0.1204 & 0.2564 \\
PO.1 & 0.4978 & 0.4371 & $\mathbf{0 . 8 3 5 7}$ & 0.3162 \\
PO.2 & 0.4550 & 0.3458 & $\mathbf{0 . 6 9 7 9}$ & 0.2817 \\
PO.3 & 0.4840 & 0.3612 & $\mathbf{0 . 7 6 2 1}$ & 0.3364 \\
PO.4 & 0.4565 & 0.4174 & $\mathbf{0 . 8 0 8 6}$ & 0.3451 \\
PO.6 & 0.4004 & 0.4252 & $\mathbf{0 . 7 3 2 5}$ & 0.3564 \\
PO.7 & 0.5603 & 0.3219 & $\mathbf{0 . 8 6 3 8}$ & 0.3621 \\
PO.9 & 0.4795 & 0.2076 & $\mathbf{0 . 8 3 1 7}$ & 0.4853 \\
PO.10 & 0.4148 & 0.2047 & $\mathbf{0 . 8 4 9 2}$ & 0.4643 \\
PO.11 & 0.3889 & 0.2409 & $\mathbf{0 . 8 0 6 3}$ & 0.4253 \\
PO.12 & 0.4347 & 0.3114 & $\mathbf{0 . 8 3 7 9}$ & 0.4610 \\
CP.1 & 0.3105 & 0.3752 & 0.3434 & $\mathbf{0 . 8 0 3 4}$ \\
CP.2 & 0.2762 & 0.2522 & 0.3481 & $\mathbf{0 . 7 8 8 5}$ \\
CP.3 & 0.3062 & 0.4117 & 0.4626 & $\mathbf{0 . 8 6 9 0}$ \\
CP.4 & 0.2689 & 0.3592 & 0.4499 & $\mathbf{0 . 9 0 3 1}$ \\
CP.5 & 0.2517 & 0.3685 & 0.3810 & $\mathbf{0 . 8 7 3 4}$ \\
CP.6 & 0.2696 & 0.2635 & 0.4072 & $\mathbf{0 . 7 8 4 1}$ \\
CP.7 & 0.2843 & 0.3971 & 0.4200 & $\mathbf{0 . 8 8 5 1}$ \\
\hline
\end{tabular}

PL: Paternalistic Leadership, MI: Management Innovation, PO: Psychological Ownership, CP: Creativity Performance Source: Created by the authors

Most of the indicator loadings were over 0.707 , which is accepted as an excellent reflective level, while item MI.6 in the management innovation construct was at a sufficient level (0.64). According to Hair et al. (2014) and Henseler, Ringle, and Sinkovics (2009), indicators having loadings between 0.40 and 0.70 must be considered as potentially significant of the factors if they do not lead to increase in the composite reliability or AVE. Other indicators with loadings lower than 0.6, four items (PL.6, PL.7, PL.11, and PL.13) from paternalistic leadership; two items (PO.5 and PO.8) from 
psychological ownership; an item (MI.4) from management innovation) were removed from the scale to improve the reliability and convergent validity of the constructs. The measurement model of this study showed a fair value concerning its reliability and validity. The results of the discriminant validity (values interval) are shown in Tables 3 and 4 .

Table 4. Latent Variable Correlation Matrix

\begin{tabular}{|l|c|c|c|c|c|c|}
\hline Variables* & Mean & SD & PL $^{* *}$ & MI $^{* *}$ & PO $^{* *}$ & P $^{* *}$ \\
\hline PL & 3.96 & 0.72 & $\mathbf{0 . 7 8}$ & & & \\
\hline MI & 3.44 & 0.80 & 0.47 & $\mathbf{0 . 7 8}$ & & \\
\hline PO & 4.24 & 0.83 & 0.57 & 0.41 & $\mathbf{0 . 8 0}$ & \\
\hline CP & 4.12 & 0.83 & 0.33 & 0.42 & 0.48 & $\mathbf{0 . 8 5}$ \\
\hline
\end{tabular}

*PL: Paternalistic Leadership, MI: Management Innovation, PO: Psychological Ownership, CP: Creativity Performance. **The bold elements are the square roots of AVE.

Source: Created by the authors

\subsection{Evaluation of the Structural Model}

The structural model is known as the inner model in PLS-SEM and delineates the relationships between latent variables and examines the predictive capabilities of the model. In PLS-SEM, the structural model is evaluated by tests, following a procedure, and determining the significance levels of collinearity of predictors, path coefficients $(\beta)$, level of coefficient of determination $\left(R^{2}\right)$ values, $f^{2}$ effect sizes, predictive relevance $\left(Q^{2}\right)$, and $q^{2}$ effect sizes (Hair et al., 2014).

Significance of the Path Coefficients $(\beta)$ and Coefficient of Determination $\left(R^{2}\right)$ Values were calculated by using SmartPLS. The data collected through the survey were analysed to test the structural model and verify the hypotheses of the study. Bootstrapping was used to assess the significance of path coefficients. The empirical $t$ values are considered for the significance of path coefficients, and $t$ values should be at least 1.96 (significance level=5\%; $p<.005$ ) for two-tailed tests. Each set of predictors in the structural model was examined for collinearity. The tolerance of each predictor construct should be higher than .20, and the variance inflation factor (VIF) should be lower than 5 (Hair et al., 2014). As presented in Table 5, the values of tolerance (> .2) and VIF (<5) were between the lower and upper thresholds.

This study revealed that paternalistic leadership had a significant and positive impact on management innovation $(\beta=.466, p<.001)$ and psychological ownership $(\beta=$ 
$.487, p<.001)$. At the same time, the study determined that management innovation had a significant and positive impact on psychological ownership $(\beta=.374, p<.001)$ and creativity performance $(\beta=.266, p<.001)$. The results also showed psychological ownership had a significant impact on creativity performance $(\beta=.178, p<.001)$, but paternalistic leadership did not have a significant impact on creativity performance $(\beta=-.005, p>.05)$. Paternalistic leadership explained $21.7 \%$ of the variance of management innovation $\left(R^{2}=.21 .7\right)$ while paternalistic leadership and management innovation explained $35 \%$ of psychological ownership $\left(R^{2}=.350\right)$. Finally, the constructs management innovation and psychological ownership together explained $28.8 \%$ of the variance in the last dependent construct creativity performance $\left(R^{2}=.288\right)$. The results of the structural path model are illustrated in Figure 2 and shown in Table 5.

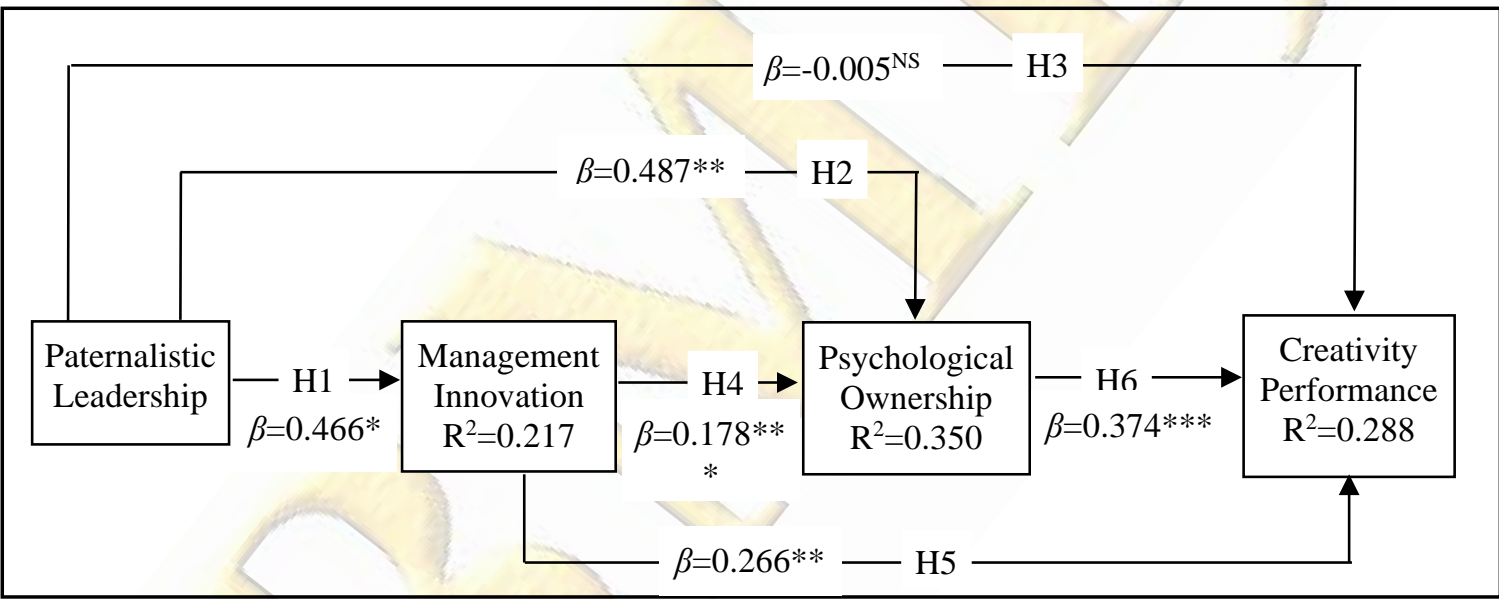

Figure 2. The Conceptual PLS-SEM Model of The Research

$$
\begin{gathered}
\text { Note. }{ }^{* *} \mathrm{p}<.001 \text {, two-tailed; NS Non-significant. } \\
\text { Source: Created by the author }
\end{gathered}
$$

As shown in Figure 2, Paternalistic Leadership had the highest path coefficient of 0.487 , which indicates that it shared a high value of variance and large effect concerning Psychological Ownership among hypothetical paths. 
Table 5. Structural Model Results (Path Coefficient and $t$-values)

\begin{tabular}{|c|c|c|c|c|c|}
\hline \multirow{3}{*}{ Hypothetical Path } & \multirow{3}{*}{$\begin{array}{c}\text { Path } \\
\text { Coeff. }(\beta)\end{array}$} & \multirow{3}{*}{ t-Values } & \multirow{2}{*}{\multicolumn{2}{|c|}{ Collinearity }} & \multirow{3}{*}{ Result } \\
\hline & & & Statist & & \\
\hline & & & Tolerance & VIF & \\
\hline $\begin{array}{c}\text { H1: Paternalistic leadership } \rightarrow \\
\text { management innovation }\end{array}$ & $.466^{* * *}$ & 14.082 & .78 & 1.28 & Supported \\
\hline $\begin{array}{l}\text { H2: Paternalistic leadership } \rightarrow \\
\text { psychological ownership }\end{array}$ & $.487^{* * *}$ & 14.340 & .67 & 1.50 & Supported \\
\hline $\begin{array}{l}\text { H3: Paternalistic leadership } \rightarrow \\
\text { creativity performance }\end{array}$ & $-.005^{\mathrm{NS}}$ & 0.094 & .88 & 1.14 & Not Supported \\
\hline $\begin{array}{l}\text { H4: Management innovation } \rightarrow \\
\text { psychological ownership }\end{array}$ & $.178^{* * *}$ & 6.636 & .83 & 1.20 & Supported \\
\hline $\begin{array}{l}\text { H5: Management innovation } \rightarrow \\
\text { creativity performance }\end{array}$ & $.266^{* * *}$ & & .82 & & Supported \\
\hline $\begin{array}{l}\text { H6: Psychological ownership } \rightarrow \\
\text { creativity performance }\end{array}$ & $.374^{* * *}$ & 6.656 & .76 & & Supported \\
\hline
\end{tabular}

Effect size $\left(f^{2}\right)$ is used to measure the impact of each independent latent variable on the latent dependent variable. If there are two or more independent variables in the construct, a specified independent variable is removed from the model, and its effect is determined by exploring the change in the $R^{2}$ value of the model. The following formula is used to measure the $f^{2}$ value (Chin, 1998):

$$
f^{2}=\frac{R^{2} \text { included }-R^{2} \text { excluded }}{1-R^{2} \text { included }}
$$

The results and inference of the $f^{2}$ effect size for the three independent latent variables of Paternalistic Leadership, Management Innovation, and Psychological Ownership are presented in Table 6.

Table 6. Results and Inference of Effect Size $f^{2}$ Estimate

\begin{tabular}{|c|c|c|c|c|c|}
\hline \multirow{3}{*}{$\begin{array}{c}\text { Independent Latent } \\
\text { Variable* }\end{array}$} & $R^{2}$ & & & \multirow{3}{*}{$\begin{array}{c}f^{2} \\
\text { Effect size }\end{array}$} & \multirow{3}{*}{ Inference } \\
\hline & \multicolumn{3}{|c|}{ Dependent Latent Variable* } & & \\
\hline & \multicolumn{2}{|c|}{$R^{2}$ Included } & $R^{2}$ Excluded & & \\
\hline PL & $\mathrm{PO}$ & .350 & .332 & .03 & Small Effect \\
\hline MI & $\mathrm{PO}$ & .350 & .170 & .28 & Medium Effect \\
\hline MI & $\mathrm{CP}$ & .288 & .178 & .15 & Medium Effect \\
\hline $\mathrm{PO}$ & $\mathrm{CP}$ & .288 & .240 & .07 & Small Effect \\
\hline
\end{tabular}

*PL: Paternalistic Leadership, MI: Management Innovation, PO: Psychological Ownership, CP: Creativity Performance. ${ }^{* *} f$ two effect size values; $\geq 0.02=$ Small, $\geq 0.15=$ Medium, and $\geq 0.35=$ Large effect (Cohen, 1988).

Source: Created by the authors 
Predictive relevance of the model was determined by examining Stone-Geisser's $Q^{2}$ value (Geisser, 1974; Stone, 1974), which is measured using blindfolding procedures (Tenenhaus, Vinzi, Chatelin, \& Lauro, 2015). The $Q^{2}$ values of the construct larger than zero for a definitive reflective endogenous latent variable indicate the path model's predictive relevance for a specific construct (Hair et al., 2014). The relative impact of predictive relevance is measured defining the $q^{2}$ effect size. The $q^{2}$ effect size can be calculated as follows:

$$
q^{2}=\frac{Q^{2} \text { included }-Q^{2} \text { excluded }}{1-Q^{2} \text { included }}
$$

The measured $q^{2}$ effect values indicate that $(\geq 0.02=$ Small, $\geq 0.15=$ Medium, and $\geq 0.35=$ Large) an exogenous latent construct has a relative impact of predictive relevance for a certain endogenous construct (Cohen, 1988; Hair et al., 2014). The results of the blindfolding procedure are shown in Table 7.

Table 7. The Results and Inference of The Effect Size $q^{2}$ Estimate

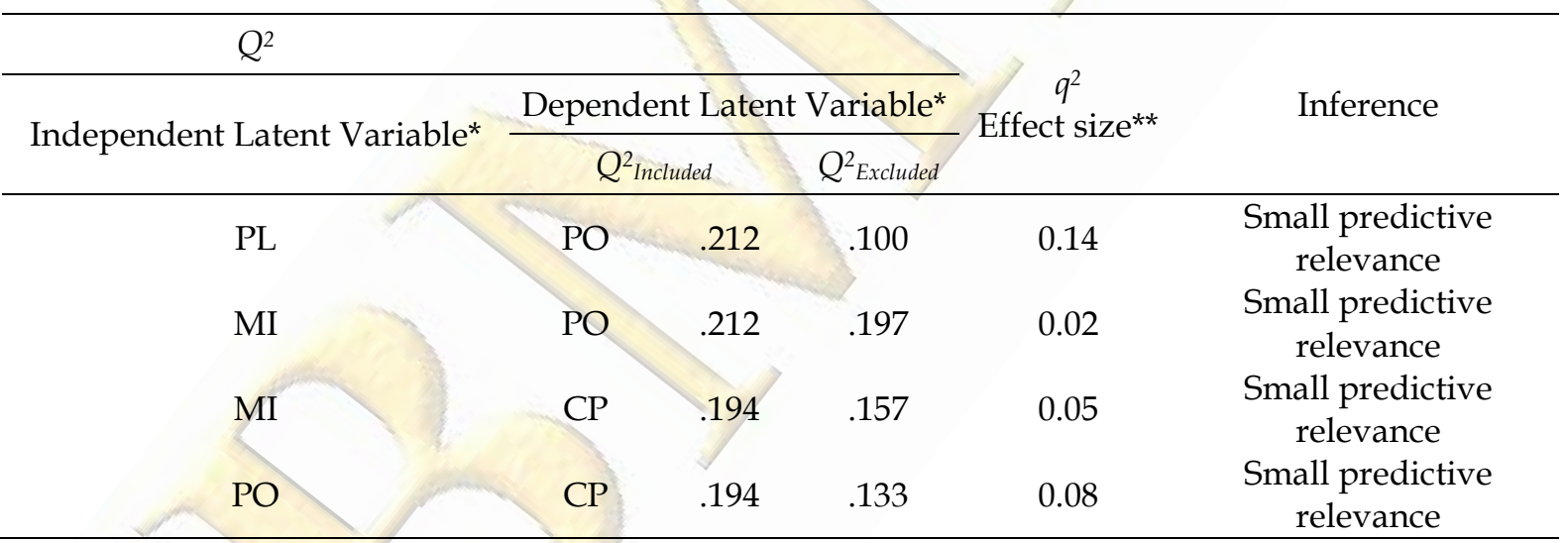

*PL: Paternalistic Leadership, MI: Management Innovation, PO: Psychological Ownership, CP: Creativity Performance.

${ }^{* *} Q^{2}$ values; $>0=$ The model has predictive relevance, $\leq 0=$ The model does not have predictive relevance.

$\mathrm{PL} \rightarrow \mathrm{MI}$ construct was not included in $q^{2}$ calculation since PL was a single independent latent variable.

Source: Created by the author

As shown in Table 7, the $Q^{2}$ values were notably over zero and the model's predictive relevance for the two endogenous constructs ( $\mathrm{PO}$ and $\mathrm{CP}$ ). Also, the three exogenous latent constructs (PL, MI, and PO) had a small relative impact in predictive relevance for a specific endogenous construct.

\section{DISCUSSION}

This study examined the impact of paternalistic leadership on management innovation, psychological ownership and creativity performance, as well as the impact 
of the management innovation and psychological ownership on creativity performance of vice-principals and principals of schools in Artvin, Turkey. The results in Table 5 indicate that five hypothetical paths $(\mathrm{H} 1, \mathrm{H} 2, \mathrm{H} 4, \mathrm{H} 5$, and $\mathrm{H} 6)$ set up in the conceptual model were significant, while the third hypothesis was not significant. The research framework had predictive power. Namely, the model was highly significant and explained $28.8 \%$ of the variance in the dependent variable $\left(R^{2}=.288\right)$. The findings of this study have several implications for the development of the theory and practice in paternalistic leadership, management innovation, psychological ownership, and organisational creativity field.

First, the results support H1, which hypothesizes that paternalistic leadership affects management innovation $\left(\beta=.466 ; R^{2}=.217 ; p<.001\right)$. The test result of the H1 hypothesis provided a perspective on the contribution of paternalistic leadership to new management practices. The results of previous research (Tian \& Sanchez, 2017) confirm the findings of this study in that paternalistic leadership stimulates the innovative behaviour of employees (Tian \& Sanchez, 2017; Wu, 2018). This study also shows that organisations should consider a paternalistic leadership approach to put innovative management into practice to increase their managerial performance (Mol \& Birkinshaw, 2009).

Second, this study, consistent with previous studies (Bernhard \& O'Driscoll, 2011; Zhu et al., 2013), revealed that paternalistic leadership had a positive and significant impact on psychological ownership $(\mathrm{H} 2: \beta=.487 ; p<.001)$. The existing literature shows that there is a supportive relationship between paternalistic leadership and positive work attitudes (Pellegrini \& Scandura, 2006; Tian \& Sanchez, 2017). Psychological ownership can be considered as a concept close to positive work attitudes. At the same time, previous studies determined that paternalistic leadership had a different effect on employees' positive attitudes (innovative behaviours, psychological ownership, commitment etc.) about the sociocultural background of the workforce (Mete \& Serin, 2015). For example, although it may have a negative effect in Europe and other Western countries, paternalistic leadership in Asian, Middle East, and Latin America societies contributes to innovative behaviours (Pellegrini \& Scandura, 2006; Aycan et al., 2000; Avey et al., 2009; Avey et al., 2012). The results from 
this empirical investigation may have significant implications in showing that a paternalistic leader, doing best for the workforce despite sometimes being autocratic, can have a positive impact on the psychological ownership of employees. Leaders or managers should treat their employees in a paternalistic manner in order to improve their psychological ownership (Pierce et al., 2001).

This study also adds a new perspective to paternalistic leadership. Cheng, Boer, Chou, Huang, Yoneyama, Shim et al. (2013) argued that the philosophy of Confucianism and cultural values, such as familism in East Asian societies were essential to the success of paternalistic leadership. However, it was determined that paternalistic leadership was also successful in Turkish society, which is not Confucian but has familial, cultural values. In this case, it can be stated that the success of paternalistic leadership is based on the cultural values of familism rather than Confucianism.

Third, the current study found that paternalistic leadership did not have a significant impact on creativity performance $(p>.05)$. In contrast to the results of this research, recent literature (Wang \& Cheng, 2010; Kurt, 2013; Dinh et al., 2014; Dedahanov et al., 2016; Wang et al., 2017; Wu, 2018) indicated that paternalistic leadership enhanced creativity performance. Thus, the findings of this study did not support the third hypothesis (H3: $p>.05)$. This result suggests that in the context of the relationship between paternal leadership and creative performance, there is no unity of perception.

Fourth, the study concluded that management innovation had a positive and significant impact on psychological ownership $(\mathrm{H} 4: \beta=.178 ; p<.001)$. From the manager's perspective, paternalistic leadership enables psychological ownership. Employees are happy when they see that their managers take an interest in their lives, sharing their joyful and sad experiences, and they consider their managers to be like a father. Employees feel they are in a family environment through this paternalistic leadership attitude, and their psychological ownership becomes more assertive in the workplace. Employees may also feel more at peace and have more commitment to the 
organisation through psychological ownership (Aycan, 2000; Pellegrini \& Scandura, 2006).

Fifth, the results showed that management innovation had a positive and significant impact on creativity performance $(\mathrm{H} 5: \beta=.266 ; p<.001)$. It was determined that the result of this study is consistent with previous studies which indicated there was a close relationship between management innovation and creativity and the performance of the company (Wang \& Netemeyer, 2004; Mol \& Birkinshaw, 2009; Volberda et al., 2013; Kraśnicka et al., 2016). Mol and Birkinshaw (2009) claimed that the use of knowledge increased the capacity of management innovation, and management innovation was attractive to analytical thinkers and well-trained employees with high creative performance. This study proposes that organisations consciously invest in management innovation in order to increase both organisational and individual creativity performance.

Finally, the results of this empirical investigation revealed that psychological ownership had a significant and positive impact on creativity performance (H6: $\beta=$ $.374 ; p<.001)$. The findings of this research are consistent with the recent work in the literature (Parks et al., 2010; Pickford et al., 2016). Creativity performance is the main factor for sustainable competitive advantage (Amabile, 1988; Chang et al., 2010; Baryniene \& Dauknyte, 2015; Thawabieh et al., 2016). In the 21st century, management innovations have become an essential factor in the success of organisations (Feigenbaum \& Feigenbaum, 2005). To achieve this, organisations should take into consideration how their employees can be more creative. As argued by Mol and Birkinshaw (2009), "firms introduce new management practices not only when market participants like consultants offer ideas, but also when they are offered by internal and professional sources." (p. 1277).

\section{CONCLUSION}

This study developed a model that demonstrates the impact of paternalistic leadership on management innovation and psychological ownership, and the impact of management innovation and psychological ownership on creativity performance. Furthermore, this study discussed how the variables of management innovation and 
psychological ownership emerged and how they related to creativity performance using a sample consisting of principals and vice-principals working in schools in Turkey. The current study developed and tested a set of hypotheses, thus contributing to the creativity performance literature. The results demonstrate that paternalistic leadership, management innovation, and psychological ownership are positively related. Besides, management innovation and psychological ownership are positively related to creativity performance. Although the results of previous research claim that paternalistic leadership is related to creativity performance (Wang \& Cheng, 2010; Kurt, 2013; Dinh et al., 2014; Dedahanov et al., 2016; Wang et al., 2017; Wu, 2018), the current findings do not provide any support for the hypothesised relationship between these variables. The limitations of this study were that there was a relatively small sample, and the participants worked in the same city, leading to a generalisation of the results of the study within a limited framework. Future research should focus on a larger sample, including other cities, and potentially incorporating other sectors. 


\section{REFERENCES}

Amabile, T.M. (1988). A Model of Creativity and Innovation in Organisations. Research in Organisational Behavior, 10, 123-167

Ansari, M. A., Ahmad, Z. A., \& Aafaqi, R. (2004). Organisational leadership in the Malaysian context. In D. Tjosvold \& K. Leung (Eds.), Leading in high growth Asia: Managing relationship for teamwork and change (pp. 109-138). Singapore: World Scientific Publishing Co.

Anwar, H. (2013). Impact of paternalistic leadership on employees' outcome a study on the banking sector of Pakistan. IOSR Journal of Business and Management, 7(6), 109-115.

Avey, J. B., Avolio, B. J., Crossley, C. R., \& Luthans, F. (2009). Psychological ownership: Theoretical extensions, measurement, and relation to work outcomes. Journal of Organizational Behavior, 30(2), 173191. https://doi.org/10.1002/job.583

Avey, J. B., Wernsing, T. S., \& Palanski, M. E. (2012). Exploring the process of ethical leadership: The mediating role of employee voice and psychological ownership. Journal of Business Ethics, 107(1), 21-34. https://doi.org/10.1007/s10551-012-1298-2.

Aycan, Z. (2006). Paternalism: Towards Conceptual Refinement and Operationalisation. In U. Kim, K.S. Yang, \& K.-K. Hwang (Eds.), Indigenous and cultural psychology: Understanding people in context (p. 445-466). Springer Science + Business Media. https://doi.org/10.1007/0-387-28662-4_20

Aycan, Z., Kanungo, R. N., Mendonca, M., Yu, K., Deller, J., Stahl, G., \& Kurshid, A. (2000). Impact of culture on human resource management practices: A 10-country comparison. Applied Psychology: An International Review, 49(1), 192-221. http://dx.doi.org/10.1111/1464-0597.00010

Baryniene, J. \& Dauknyte, B. (2015). Creativity as the main factor for organisations' success: Theoretical approach. European Integration Studies, 9, 235-243. http://dx.doi.org/10.5755/j01.eis.0.9.12810

Bernhard, F., \& O'Driscoll, M. P. (2011). Psychological ownership in small family-owned businesses: Leadership style and nonfamily-employees' work attitudes and behaviors. Group and Organization Management, 36(3), 345-384. https:// doi.org/10.1177/1059601111402684

Birkinshaw, J., Hamel, G., \& Mol, M. J. (2008). Management innovation. Academy of Management Review, 33(4), 825-845.

Camisón, C., \& Villar-López, A. (2014). Organisational innovation as an enabler of technological innovation capabilities and firm performance. Journal of Business Research, 67, 2891-2902. https:// doi.org/10.1016/j.jbusres.2012.06.004

Chang, S.C, Tein, S.W. \& Lee, H.M. (2010). Social capital, creativity, and new product advantage: an empirical study. International Journal of Electronic Business Management, 8(1), 43-55.

Cheng, B.S., Boer, D., Chou, L. F., Huang, M. P., Yoneyama, S., Shim, D. et al. (2013). Paternalistic leadership in four East Asian Societies. Journal of Cross-Cultural Psychology, XX(X), 1-9. DOI: $10.1177 / 0022022113490070$

Chin, W.W. (1989). The partial least square approach forstructural equation modeling. In G.A. Marcoulides (Ed.), Modern Methods for Business Research (pp. 295-336), Mahwah: Lawrence Erlbaum Associates. 
Cohen, J. (1988). Statistical power analysis for the behavioural sciences. Lawrence Erlbaum Associates Hillsdale, New Jersey.

Daniels, S. R. \& Jordan, S. L. (2018). The Effect of Paternalism on Incivility: Exploring Incivility Climate as an Important Boundary Condition. Journal of Leadership \& Organizational Studies, 26(2), 190-203. https://doi.org/10.1177/1548051818795817

Dedahanov, A. T., Lee, D. H., Rhee, J., \& Yoon, J. (2016). Entrepreneur's paternalistic leadership style and creativity: The mediating role of employee voice, Management Decision, 54(9), 2310-2324, https://doi.org/10.1108/MD-11-2015-0537

Ding, X., Tang, Y-Y., Tang, R., \& Posner, M.I. (2014). Improving creativity performance by short-term meditation. Behavioral and Brain Functions, 10(9), 1-8. https://doi.org/10.1186/1744-9081-10-9

Dinh, J. E., Lord, R. G., Gardner, W. L., Meuser, J. D., Liden, R. C., \& Hu, J. (2014). Leadership theory and research in the new millennium: Current theoretical trends and changing perspectives. The Leadership Quarterly, 25(1), 36-62. https://doi.org/10.1016/j.leaqua.2013.11.005

Farh J. L., \& Cheng B. S. (2000). A cultural analysis of paternalistic leadership in Chinese organisations. In Li J.T., Tsui A.S., Weldon E. (Eds.), Management and Organisations in the Chinese Context (pp. 84-127), London: Palgrave Macmillan.

Farh, J. L., Cheng, B. S., Chou, L. F., \& Chu, X. P. (2006). Authority and benevolence: Employee's responses to paternalistic leadership in China. In A. S. Tsui, Y. Bian, \& L. Cheng (Eds.), China's Domestic Private Firms: Multidisciplinary Perspectives on Management and Performance (pp. 230-260), Armonk, NY: Sharpe.

Feigenbaum, A.V. \& Feigenbaum, D.S. (2005). What quality means today. Sloan Management Review, $46(2), 96$.

Fornell, C., \& Larcker, D. F. (1981). Evaluating structural equation models with unobservable variables and measurement error. Journal of Marketing Research, XVIII, 39-50. DOI: 10.2307/3151312

$\mathrm{Fu}, \mathrm{X} ., \mathrm{Li}, \mathrm{Y} ., \mathrm{Si}$, Y. (2013). The impact of paternalistic leadership on innovation: An integrated model. Nankai Business Review International, 4(1), 9-24, https:/ / doi.org/10.1108/20408741311303850

Geisser, S. (1974). A predictive approach to the random effects model. Biometrika, 61(1), 101-107. DOI: $10.2307 / 2334290$

Gino, F. (2015). How to make employees feel like they own their work. Harvard Business Review, Retrieved from https://hbr.org/2015/12/how-to-make-employees-feel-like-they-own-their-work (26.08.2018).

Griep, Y., Wingate, T., \& Brys, C. (2017). Integrating psychological contracts and psychological ownership: The role of employee 1deologies, organisational culture and organisational citizenship behaviour. In Olckers, C., van Zyl, L., van der Vaart, L. (Eds.), Theoretical orientations and practical applications of psychological ownership (pp.79-101), Vanderbijlpark: Springer International Publishing. DOI: 10.1007/978-3-319-70247-6_5 
Hair, J. H., Hult, G. M., Ringle, C. M., \& Sarstedt, M. (2014). A primer on partial least squares structural equation modeling (PLS-SEM). Los Angeles: SAGE Publications.

Hamel, G. \& Breen, Bill (2007). The future of management. Harvard Business Press, Boston, USA. ISBN: 9781422102503.

Henseler, J., Ringle, C. M., \& Sinkovics, R. R. (2009). The use of partial least squares path modeling in international marketing, In R. R. Sinkovics, P.N. Ghauri (Eds.) New Challenges to International Marketing (Advances in International Marketing, Volume 20), (pp.277-319), Emerald Group Publishing Limited. doi:10.1108/S1474-7979(2009)0000020014

Karakitapoğlu-Aygün, Z., Gumusluoglu, L., \& Scandura, T. A. (2019). How Do Different Faces of Paternalistic Leaders Facilitate or Impair Task and Innovative Performance? Opening the Black Box. Journal of Leadership E Organizational Studies, 27(2), 138-152. https://doi.org/10.1177/1548051819833380

Kim, U.M. (1994). Significance of paternalism and communalism in the occupational welfare system of Korean firms: A national survey. In U. Kim, H. C. Triandis, C. Kagitcibasi, S. Choi \& G. Yoon (Eds.), Individualism and Collectivism: Theory Method, and Applications (pp. 251-266), London: Sage Publications. Kirk, C. P., McSherry, B. \& Swain, S. D. (2015). Investing the self: The effect of nonconscious goals on investor psychological ownership and word-of-mouth intentions. Journal of Behavioral and Experimental Economics, 58, 186-194. https://doi.org/10.1016/j.socec.2015.04.013

Kraśnicka, T., Głód, W., \& Wronka-Pośpiech, M. (2016). Management innovation and its measurement. Journal of Entrepreneurship. Management and Innovation (JEMI), 12(2), 95-122. https://doi.org/10.7341/20161225

Kurt, İ. (2013). A research study on the relationship between paternalistic leadership and employee creative work involvement perceptions. Sosyal ve Beşeri Bilimler Dergisi, 5(1), 321-330.

Lee, W.G., Jeon, Y.H., Kim, J.W., \& Jung, C.Y. (2014). Effects of job security and psychological ownership on turnover intention and innovative behavior of manufacturing employees. Journal of the Korea Safety Management and Science, 16(1), 53-68. https://doi.org/10.12812/ksms.2014.16.1.53

Li, C. R., Li, C. X., \& Lin, C. J. (2019). The effect of individual task conflict on employee creativity: A moderated mediation model. Thinking Skills and Creativity, 31, 112-124. https:// doi.org/10.1016/j.tsc.2018.11.006

Lin, C. \& Zhuang, B. (2014). The impact of paternalistic leadership on management innovation: an integrated model. Studies in Science of Science, 32(4), 1-10.

Lin, W., Ma, J., Zhang, Q., Lin, J. C., \& Jiang, F. (2016). How is benevolent leadership linked to employee creativity? The mediating role of leader-member exchange and the moderating role of power distance orientation. Journal of Business Ethics, 152(4), 1099-1115. https://doi.org/10.1007/s10551016-3314-4. 
Lu, L., Li, F., Leung, K., Savani, K., \& Morris, M.W. (2017). When can culturally diverse teams be more creative? The role of leaders' benevolent paternalism. Journal of Organizational Behavior, 39(4), 402-415. https://doi.org/10.1002/job.2238

Mete, Y. A. \& Serin, H. (2015). Okul yöneticilerinin babacan liderlik davranışı ile öğretmenlerin örgütsel vatandaşlık ve örgütsel sinizm davranışları arasındaki ilişki (In English: Relationship between school administrators' paternalist leadership behaviours and teachers' organizational citizenship and organizational cynicism behaviours). HAYEF: Journal of Education, 12(24), 147-159.

Mol, M. J., \& Birkinshaw, J. (2006). Against the flow: Reaping the rewards of management innovation. European Business Forum, 27, 24-29. https://doi.org/10.1016/j.jbusres.2009.01.001

Mol, M. J., \& Birkinshaw, J. (2009). The sources of management innovation: When firms introduce new management practices. Journal of Business Research, 62, 1269-1280. https:// doi.org/10.1016/j.jbusres.2009.01.001

Mustafa, M., Martin, L., \& Hughes, M. (2016). Psychological ownership, job satisfaction, and middle manager entrepreneurial behavior. Journal of Leadership and Organizational Studies, 23(3), 272-287. https://doi.org/10.1177/1548051815627360

Nal, M., \& Tarım, M. (2017). Sağlık Yöneticilerinin Paternalist (Babacan) Liderlik Davranışlarının Çalışanların İş Doyumu Üzerine Etkisi. Artvin Çoruh Üniversitesi Uluslararası Sosyal Bilimler Dergisi, 3(2), 117-141. https://doi.org/10.22466/acusbd.341461

Nal, M. (2019). The impact of the paternalist leadership on organisational cynicism: A research in the health sector. Journal of International Health Sciences and Management, 5(9), 44-53.

Nal, M. \& Sevim, E. (2019). Paternalist liderliğin iş motivasyonu üzerine etkisi: Sağlık çalışanları üzerinde bir araştırma. Gümüşhane Üniversitesi Sağlık Bilimleri Dergisi, 8(4), 397-410.

Nal, M. \& Sevim, E. (2020). The Effect of Paternalist Leadership on Work Engagement: A Research on Health Workers. Journal of International Health Sciences and Management, 6(10): 90-107. https://dergipark.org.tr/tr/pub/jihsam/issue/53910/652891

Nunally, J. C. \& Bernstein, I. (1994). Psychometric Theory. New York: McGraw Hill.

Özyılmaz, B., \& Ataç, L. O. (2019). Paternalist liderlik algısının çalışan sesliliğine etkisi: Gıda sektörü çalışanları üzerine bir araştırma. Celal Bayar Üniversitesi İktisadi ve İdari Bilimler Fakültesi Yönetim ve Ekonomi Dergisi, 26(2), 397-410. https://doi.org/10.18657/yonveek.574425

Parks, J.M., Ma, L., \& Gallagher, D.G. (2010). Elasticity in the 'rules' of the game: Exploring organisational expedience. Human Relations, 63(5), 701-730. https:/ / doi.org/10.1177/0018726709355331 Pasa, S.F., Kabasakal, H. \& Bodur, M. (2001). Society, organisations, and leadership in Turkey. Applied Psychology: An International Review, 50(4): 559-589. https://doi.org/10.1111/1464-0597.00073

Pellegrini, E. K.\& Scandura, T. A. (2006). Leader-member exchange (LMX), paternalism, and delegation in the Turkish business culture: An empirical investigation. Journal of International Business Studies, 37, 264-279. https:// doi.org/10.1057/palgrave.jibs.8400185 
Pellegrini, E. K., Scandura, T. A., \& Jayaraman, V. (2010). Cross-cultural generalizability of paternalistic leadership: An expansion of leader-member exchange theory. Group \& Organization Management 35(4), 391-420. https://doi.org/10.1177/1059601110378456

Pickford, H.C., Joy, G., \& Roll, K. (2016). Psychological Ownership effects and applications. Saïd Business School Research Papers, University of Oxford. Retrieved from: http://eureka.sbs.ox.ac.uk/6266/1/201632.pdf (09.09.2018).

Pierce, J.L., Kostova, T. \& Dirks, K.T. (2001). Toward a theory of psychological ownership in organisations. Academy of Management Review, 26(2), 298-310. DOI: 10.2307/259124

Ringle, C.M., Wende, S., \& Will, A. (2005), SmartPLS 2.0 (beta), http://www.smartpls.de.

Seppala, E. (2015). To motivate employees, do 3 things well. Harvard Business Review, Retrieved from https://hbr.org/2016/01/to-motivate-employees-do-3-things-

ell?referral=03759\&cm_vc=rr_item_page.bottom (26.08.2018).

Shukla, A. \& Singh, S. (2015). Psychological ownership: scale development and validation in the Indian context. International Journal of Indian Culture and Business Management, 10(2), 230-251. https:// doi.org/10.1504/IJICBM.2015.068172

Stone, M. (1974). Cross-validatorychoice and assessment of statistical predictions. Journal of the Royal Statistical Society, 36(2), 111-147.

Sungur, C., Özer, Ö., Saygılı, M., \& Uğurluoğlu, Ö. (2019). Paternalistic leadership, organisational cynicism, and intention to quit one's job in nursing. Hospital Topics, 97(4), 139-147. https://doi: 10.1080/00185868.2019.1614893

Tenenhaus, M., Vinzi, V. E., Chatelin, Y. M., \& Lauro, C. (2005). PLS Path Modelling. Computational Statistics and Data Analysis, 48(1), 159-205. https:// doi.org/10.1016/j.csda.2004.03.005

Thawabieh, F.A., Saleem, M., \& Hashim, M.W. (2016). Organisational Creativity and Competitive Advantage: A GCC Perspective. International Journal of Economic and Management Sciences, 5(4): 355. doi:10.4172/2162-6359.1000355

Tian, Q. \& Sanchez, J. S. (2017). Does paternalistic leadership promote innovative behavior? The interaction between authoritarianism and benevolence. Journal of Applied Social Psychology, 47(5), 235246. https://doi.org/10.1111/jasp.12431

Tierney, P. \& Farmer, S. M. (2002). Creative self-efficacy: Its potential antecedents and relationship to creative performance. The Academy of Management Journal, 45(6), 1137-1148. https://doi.org/10.5465/3069429

Tierney, P., \& Farmer, S. M. (2011). Creative self-efficacy development and creative performance over time. Journal of Applied Psychology, 96(2), 277-293. http://dx.doi.org/10.1037/a0020952

Uğurluoğlu, O., Aldoğan, E. U., Turgut, M., \& Özatkan, Y. (2018). The effect of paternalistic leadership on job performance and intention to leave the job. Journal of Health Management, 20(1), 46-55. https://doi.org/10.1177/0972063417747700 
Uhl-Bien, M., Tierney, P. S., Graen, G. B. \& Wakabayashi, M. (1990). Company Paternalism and the Hidden-Investment Process: Identification of the "Right Type" for Line Managers in Leading Japanese $\begin{array}{llll}\text { Organisations. Group } \quad \text { Organization } & \text { Management, } & \text { 15(4), }\end{array}$ https:// doi.org/10.1177/105960119001500406

Wang, A. C., \& Cheng, B. S. (2010). When does benevolent leadership lead to creativity? The moderating role of creative role identity and job autonomy. Journal of Organizational Behavior, 31(1), 106-121. https://doi.org/10.1002/job.634

Wang, G. \& Netemeyer, R.G. (2004). Salesperson creative performance: conceptualisation, measurement, and nomological validity. Journal of Business Research, 57, 805-812. https:// doi.org/10.1016/S0148-2963(02)00483-6

Wang, Y., Tang, C., Naumann, S., \& Wang, Y. (2017). Paternalistic leadership and employee creativity: A mediated moderation model. Journal of Management $\mathcal{E}$ Organization, 1-20. https://doi.org/10.1017/jmo.2017.8

Wang, S-M., Chou, W-J., Wu, T-Y., \& Cheng, B-S. (2018). The Double-edged sword of benevolence: A dual paths model of benevolent leadership and creative performance. Chinese Journal of Psychology, 60(1), 57-79. DOI: 10.6129/CJP.201803_60(1).0003

Wu, Y.S. (2018) The Influence of Paternalistic Leadership on the Creative Behavior of Knowledge Workers-Based on the Perspective of Psychological Contractual Perception. Open Journal of Business and Management, 6, 478-487. https://doi.org/10.4236/ojbm.2018.62036.

Vaccaro, I.G., Jansen, J.J.P, Van Den Bosch, F.A.J., \& Volberda, H.W. (2012). Management innovation and leadership: The moderating role of organisational size. Journal of Management Studies, 49(1), 28-51. https://doi.org/10.1111/j.1467-6486.2010.00976.x

Volberda, H.W., Van Den Bosch, F.A.J. \& Heij, C.V. (2013). Management Innovation: Management as fertile ground for innovation. European Management Review, 10, 1-15. https://doi.org/10.1111/emre.12007

Volberda, H.W., Bosch, F.A.J.V.D., \& Mihalache, O.R. (2014). Advancing Management Innovation: Synthesising Processes, Levels of Analysis, and Change Agents. Organisation Studies, 35(9) 1245-1264. https://doi.org/10.1177/0170840614546155

Yeşiltaş, M. (2013). The Effects of Paternalist Leadership on Organizational Citizenship Behavior: Mediating Role of Distributive Justice. Journal of Business Research-Türk, 5(4), 50-70.

Zhou, J. \& George, J.M. (2001). When job dissatisfaction leads to creativity: Encouraging the expression of voice. Academy of Management Journal, 44(4), 682-696. https:/ / doi.org/10.5465/3069410

Zhu, H., Chen, C. C., Li, X. C., \& Zhou, Y. H. (2013). From personal relationship to psychological ownership: The importance of manager-owner relationship closeness in family businesses. Management and Organization Review, 9(2), 295-318. https://doi.org/10.1111/more.12001. 